\title{
EFFECT OF MAGNETIZED IRRIGATION WATER LEVELS AND COMPOST ON VEGETATIVE GROWTH, LEAF MINERAL CONTENT AND WATER USE EFFICINECY OF WASHINGTON NAVEL ORANGE TREES \\ Mostafa, M. F. M' ${ }^{1}$; M.S.S. El-Boray ${ }^{1}$; A.M. N. Shalan and A. H. Ghaffar \\ 1-Pomology.Dept.Fac.Agric., Mansoura. Univ., Egypt.
}

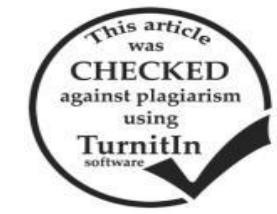

\begin{abstract}
This investigation was carried out during two successive seasons of 2014 and 2015 on 6 years old, Washington Navel orange trees (Citrus sinensis L.) budded on sour orange rootstock. Tree spaced at 5 x 5 meter and grown on sandy soil and irrigated with saline water (EC was $4 \mathrm{ds} / \mathrm{m}$ ) under drip irrigation system in private orchard located at El-Behera Governorate, Egypt. The objection to study the impact of different levels of magnetized irrigation water and compost on growth, leaf mineral content and water use efficiency (WUE) of Washington Navel orange tree growing on sandy soil under drip irrigation saline water. Three levels of magnetized irrigation water 3658.5, 2743.8 and $1829 \mathrm{~m} 3 / \mathrm{fed}$. with and without compost at $4 \mathrm{~kg} / \mathrm{tree}$ along with control (non-magnetic water).

Results indicated that, the highest values of vegetative growth parameters i.e., shoot length, shoot thickness, number of leaves/shoot, leaf area/leaf, as well as chemical constituents of leaves $(\mathrm{N}, \mathrm{P}, \mathrm{K}, \mathrm{Ca}, \mathrm{Mg}$ ) obtained by trees irrigated with magnetized water levels combined with or without compost. Leaf $\mathrm{Na}$ content were increased under control treatment(nonmagnetic water). The best results of both vegetative growth parameters and chemical constituents of leaves were recorded when trees irrigated with magnetized water at level $1(3658.5 \mathrm{~m} 3 / \mathrm{fed} / \mathrm{season})+4 \mathrm{~kg}$ compost followed by level $2(2743.8 \mathrm{~m} 3 / \mathrm{fed} / \mathrm{season})$ $+4 \mathrm{~kg}$ compost, while the highest yield efficiency (YE) and WUE obtained from irrigation treatment at level3(1829 $\mathrm{m} 3 / \mathrm{fed} / \mathrm{season})+4 \mathrm{~kg}$ compost in both seasons .Therefore, magnetizing water at level $1+4 \mathrm{~kg}$ compost or level $2+4 \mathrm{~kg}$ compost treatment could be recommended for improving citrus trees performance under saline water conditions.
\end{abstract}

Keywords: water salinity, magnetized water, growth, orange trees.

\section{INTRODUCTION}

Citrus is one of the most important world fruit crops. However, citrus in Egypt is ranked the first in this respect. The area of citrus trees has increased rapidly through the last few years and reached about 518694 feddans (According to the yearly Bull. Agric. Economic and Statistics, Ministry of Agriculture and Land Reclamation of Egypt, 2014). Navel orange is a popular fresh fruit due to its seedless ness, large sized, characterized flavor and aroma, also is an important source of early season income for citrus growers in each commercial citrus areas of the world (Wardowski et al.1985). In Egypt agriculture is the main consumed than $80 \%$ the available water for irrigation and crop production. An additional water may expected in future than the present to face the population increase and food production (Mohamed, 2013). Saline water of may represent a possible water supply, but its salinily is one of the most problems may a negative affect plants through three limited components: osmotic, nutrition's and toxic stresses (Munns, 1993). When exposed to salinity, growth and development tend to decline, with consequent reduction in their economic value. The use of saline water for agricultural production in water insufficiency regions requires innovative and sustainable research, and an appropriate transfer of technologies. There is a pressing need for a system (technology role e.g. magnetic water). The water treated by passing through a magnetic device called magnetized water. Magnetized water was shown to have three main effects: increasing the leaching of excess soluble salts, lowering soil alkalinity and dissolving slightly soluble salts such carbonates, phosphates and sulfates. However, the degree of effectiveness of magnetized water on soil salinity and ionic balance in soil solution depended greatly on the traveling distance of magnetized water along the drip irrigation lines (Hilal and Hilal, 2000). Magnetic water may improv the plant growth characteristics and nutrients uptake (Radhakrishnan and Kumari, 2012), root function (Aladjadjiyan, 2010), influenced the chemical composition of plants, activate plant enzymes (Alikamanoglu and Sen, 2011). New strategy of fertilization depends on using recycled animal manure and farm residues to produce compost for enhancing biological cycles, improving soil fertility and counter attack against all forms of pollution that may result from conventional agriculture techniques (Shiralipour et al., 1992). The application of compost also improving the soil characteristics; increasing soil fertility and organic matter content. Compost application can compensate use of chemical fertilizers, which have adverse environmental effects. Also the use of organic fertilizers increasing the crop productivity, increasing the soil fertility and the water requirements was decreasing with using compost (saving water) (Natsheh and Mousa, 2014).

The objective of the current study is to evaluate the effect of different levels of magnetized irrigation water and compost on vegetative growth, leaf mineral contents and water use efficiency of Washington Navel orange trees growing on sandy soil under drip irrigation with saline water.

\section{MATERIALS AND METHODS}

This investigation was carried out during two successive seasons of 2014 and 2015 on 6 years old, Washington Navel orange trees (Citrus sinensis L.) budded on sour orange rootstock, spaced at $5 \times 5$ meter and grown on sandy soil and irrigated with saline 
water(EC was $4 \mathrm{ds} / \mathrm{m}$ )under drip irrigation system in private orchard located at El-Behera governorate, Egypt. The trees were subjected to normal cultural practices which usually done in this area.The mean values of Table (1): physical and chemical and properties of experimental soil .

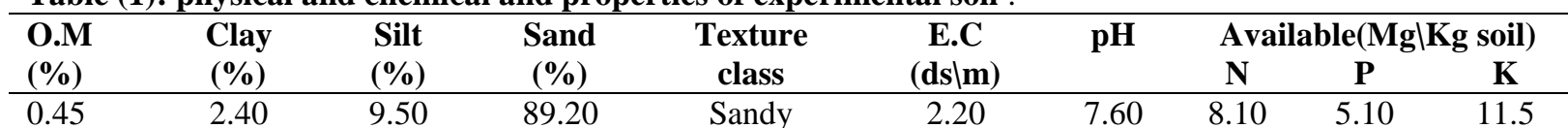

The selected trees were grouped under seven treatments in each season. Each treatment was represented by three replicates, thus each replicate contained three trees. The recommended rate of nitrogen fertilization was added according to ministry of agriculture. The seven treatments involved in this study were summarized as follows:

1. Control (non-magnetizing) normal ordinary saline irrigation water pumped from a well at $3658.5 \mathrm{~m}^{3} / \mathrm{fed} / \mathrm{season}$ (16 drippers / tree).

2. Magnetized irrigation water at $3658.5 \mathrm{~m} 3 / \mathrm{fed} / \mathrm{season}$ (level1=16 drippers / tree).

3. Magnetized irrigation water at $2743.8 \mathrm{~m}^{3} / \mathrm{fed} / \mathrm{season}$ (level2=12 drippers / tree). some physical and chemical properties of the experimental soil are presented in Table (1).

Table (2). Chemical analysis of compost used in the experiment.

\begin{tabular}{lc}
\hline Properties & Values \\
\hline Weight of dry $\mathrm{m}^{3}(\mathrm{~kg})$ & 590 \\
Weight of wet $\mathrm{m}^{3}(\mathrm{~kg})$ & 730 \\
Humidity $(\%)$ & 24 \\
$\mathrm{pH}(1-10)$ extract & 6.6 \\
$\mathrm{EC}(1-10)(\mathrm{ds} / \mathrm{m})$ & 1.6 \\
Total nitrogen $(\%)$ & 1.4 \\
Ammonium nitrogen $(\mathrm{ppm})$ & 550 \\
Nitrogen nitrate $(\mathrm{ppm})$ & 315 \\
Organic matter $(\%)$ & 58 \\
Organic carbon $(\%)$ & 52.2 \\
Ash $(\%)$ & 42 \\
C/N ratio & $18: 1$ \\
Total phosphorus $(\%)$ & 0.6 \\
Total potassium $(\%)$ & 0.79 \\
\end{tabular}

Table (3): The irrigation program and amount of irrigation water applied $\left(\mathrm{m}^{3} / \mathrm{fed}\right)$ in the different irrigation treatments during both growing seasons.

\begin{tabular}{|c|c|c|c|c|c|c|c|c|c|c|c|c|c|c|c|c|c|}
\hline \multirow{3}{*}{$\sum_{\Sigma}^{\mathscr{E}}$} & \multirow{3}{*}{ 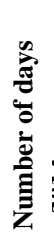 } & \multicolumn{2}{|c|}{$\begin{array}{c}\text { water } \\
\text { applied } \\
\text { l/day }\end{array}$} & \multicolumn{14}{|c|}{ Treatments } \\
\hline & & & & \multicolumn{2}{|c|}{ T1 } & \multicolumn{2}{|c|}{$\mathbf{T} 2$} & \multicolumn{2}{|c|}{ T3 } & \multicolumn{2}{|c|}{ T4 } & \multicolumn{2}{|c|}{ T5 } & \multicolumn{2}{|c|}{ T6 } & \multicolumn{2}{|c|}{ T7 } \\
\hline & & & $\stackrel{n}{\frac{n}{8}}$ & ষ্ন & $\stackrel{n}{\frac{\pi}{8}}$ & $\underset{\nabla}{\mathbb{d}}$ & $\stackrel{n}{\frac{\pi}{3}}$ & $\underset{\nabla}{\mathbb{\tau}}$ & $\frac{n}{\sqrt{2}}$ & ষ্ঠ & $\frac{n}{8}$ & 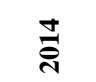 & $\stackrel{n}{\stackrel{\sim}{*}}$ & $\underset{\nabla}{\mathbb{\nabla}}$ & $\frac{n}{8}$ & ষ্ণ & $\frac{n}{\overline{8}}$ \\
\hline January & 31 & 37 & 33 & 1147 & 1023 & 860.3 & 767.3 & 573.5 & 511.5 & 1147 & 1023 & 860.3 & 767.3 & 573.5 & 511.5 & 1147 & 1023 \\
\hline February & 28 & 46 & 42 & 1288 & 1176 & 966 & 882 & 644 & 588 & 1288 & 1176 & 966 & 882 & 644 & 588 & 1288 & 1176 \\
\hline March & 31 & 53 & 51 & 1643 & 1581 & 1232.3 & 1185.3 & 821.5 & 790.5 & 1643 & 1581 & 1232.3 & 1185.3 & 821.5 & 790.5 & 1643 & 1581 \\
\hline April & 30 & 65 & 60 & 1950 & 1800 & 1462.5 & 1350 & 975 & 900 & 1950 & 1800 & 1462.5 & 1350 & 975 & 900 & 1950 & 1800 \\
\hline May & 31 & 80 & 75 & 2480 & 2325 & 1860 & 1743.3 & 1240 & 1162.5 & 2480 & 2325 & 1860 & 1743.3 & 1240 & 1162.5 & 2480 & 2325 \\
\hline June & 30 & 85 & 80 & 2550 & 2400 & 1912.5 & 1800 & 1275 & 1200 & 2550 & 2400 & 1912.5 & 1800 & 1275 & 1200 & 2550 & 2400 \\
\hline July & 31 & 92 & 88 & 2852 & 2728 & 2139 & 2046 & 1426 & 1364 & 2852 & 2728 & 2139 & 2046 & 1426 & 1364 & 2852 & 2728 \\
\hline August & 31 & 76 & 72 & 2356 & 2232 & 1767 & 1674 & 1178 & 1116 & 2356 & 2232 & 1767 & 1674 & 1178 & 1116 & 2356 & 2232 \\
\hline September & 30 & 75 & 71 & 2250 & 2130 & 1687.5 & 1597.5 & 1125 & 1065 & 2250 & 2130 & 1687.5 & 1597.5 & 1125 & 1065 & 2250 & 2130 \\
\hline October & 31 & 62 & 58 & 1922 & 1798 & 1441.5 & 1348.5 & 961 & 899 & 1922 & 1798 & 1441.5 & 1348.5 & 961 & 899 & 1922 & 1798 \\
\hline November & 30 & 40 & 36 & 1200 & 1080 & 900 & 810 & 600 & 540 & 1200 & 1080 & 900 & 810 & 600 & 540 & 1200 & 1080 \\
\hline December & 31 & 28 & 25 & 868 & 778 & 650 & 581 & 434 & 387.5 & 868 & 778 & 650 & 581 & 434 & 387.5 & 868 & 778 \\
\hline $\mathrm{m}^{3} /$ tree/ yea & & - & - & 22,506 & 21,048 & 16,879 & 15,786 & 11,253 & 10,524 & 22,506 & 21,048 & 16,879 & 15,786 & 11,253 & 10,524 & 22,506 & 21,048 \\
\hline $\mathrm{m}^{3} /$ fed./ye & & - & - & 3781 & 3536 & 2835.6 & 2652 & 1890 & 1768 & 3781 & 3536 & 2835.6 & 2652 & 1890 & 1768 & 3781 & 3536 \\
\hline
\end{tabular}




\section{Vegetative growth parameters:}

Four branches on each direction were chosen and labeled in each tree for measuring and determination the vegetative parameters,i.e shoot length, shoot thickness, number of leaves/ shoot, leaf area/leaf $\left(\mathrm{cm}^{2}\right)$ was calculated according to the equation of (Chou, 1966). Leaf area $=2 / 3$ length $\times$ width, leaf dry weight $(\mathrm{g})$ and leaf specific weight $\left(\mathrm{mg} / \mathrm{cm}^{2}\right)$ It was calculated according to Ferre and Forshey (1988) as follows SLW $=$ leaf dry weight $(\mathrm{mg}) /$ leaf area $\left(\mathrm{cm}^{2}\right)$.

Water use efficiency $\left(\mathrm{kg} / \mathrm{m}^{3}\right)$

Water use efficiency (WUE) was used to evaluate the comparative benefits of the different irrigation treatments. It was calculated according to Hansen et al. (1980) by the following equation:

$$
\text { WUE }\left(\mathrm{kg} / \mathrm{m}^{3}\right)=\frac{\text { Yield }(\mathrm{kg} / \text { fed })}{\text { Water }\left(\mathrm{m}^{3} / \mathrm{fed} / \text { season }\right)}
$$

\section{Leaf mineral content}

The leaves sample were taken at September and washed with tap water followed by distilled water. Leaves fresh weight was calculated then the leaves were oven dried at $70 \mathrm{oC}$ to a constant weight. Dry weight was calculated then the dry leaves were ground and digested according to Chapman and Pratt (1961) and Jackson (1967) by using the mixture of concentrated Sulfuric acid $\left(\mathrm{H}_{2} \mathrm{SO}_{4}\right)+$ per chloric $\left(\mathrm{HCLO}_{4}\right)(5: 1)$ to determine the elements . N, P, K, Ca, Mg and $\mathrm{Na}$. Total nitrogen \% was determined by using the microkjheldahl method as described by Pregle (1945), Phosphorus \% was determined colorimetric ally as described by Murphy and Riley (1962) while, Potassium $\%$ e was estimated by using flame photometer as described by Brown and Lille land (1974) also, Calcium, Magnesium and Sodium were determined using atomic absorption spectrophotometer Perkin Elmer model 2380 according to Wilde et al. (1985) and Chloride it was estimated by titration method according to Jackson (1958).

\section{Statistical analysis}

The obtained data were statistically analyzed as randomized complete block design according to (Snedecor and Cochran, 1977) and treatment means were compared using Duncan Multiple Range Test (DMRT) (Duncan, 1955).

\section{RESULTS AND DISCUSSION}

Effect of magnetizing irrigation water levels and compost on vegetative growth, fruit set, yield, water use efficiency, fruit quality and chemical composition of Washington Navel orange trees are included in this study.

\section{1-Vegetative growth:}

Shoot length, thickness and number of leaves /shoot

Data in Table (4) showed that the vegetative growth parameters like as shoot length, shoot thickness and number of leaves /shoot significantly increased with levels all magnetizing irrigation water + compost treatments during two seasons of the study comparing to control (non-magnetic water).Also, previous vegetative growth parameters were significant increased when used magnetic irrigation water at $3658.5 \mathrm{~m} 3 / \mathrm{fed} / \mathrm{season}+4 \mathrm{~kg}$ compost/tree followed by magnetic irrigation water at $2743.8 \mathrm{~m} 3 / \mathrm{fed} / \mathrm{season}+4 \mathrm{~kg}$ compost/tree compared with magnetic water levels and control(non-magnetic water) This increment was statistically significant in both seasons.. Our results were in harmony with the conclusion given by Wassel et al. (2007) on Balady mandarin trees, El-Sayed and Ennab (2013) worked on Valencia orange trees, Hussien et al. (2013) on Washington Navel orange trees and Júnior et al., (2011) on acid lime. They reported that plant height, shoot length and number of leaves was increased by raising the amount of water.However, Aly et al. (2015). They showed that application of magnetic water improved growth of Valencia oranges trees compared to nonmagnetic treatment. Also, Zhou et al. (2001), Mansour and Shaaban (2007) and Zalat (2014) who revealed that growth of citrus trees significantly affected by compost application.

Table (4): Effect of magnetic irrigation water levels and compost on shoot length, thickness and number of leaves per shoot of spring cycle of Washington Navel orange trees in 2014 and 2015 seasons.

\begin{tabular}{lcccccc}
\hline Treatments & \multicolumn{2}{c}{ Shoot length $(\mathbf{c m})$} & \multicolumn{2}{c}{ Shoot thickness $(\mathbf{m m})$} & \multicolumn{2}{c}{ No. of leaves/shoot } \\
& 2014 season & 2015 season & 2014 season & 2015 season & 2014 season & 2015 season \\
\hline Control (non magnetic water) & 4.967 & 4.300 & 2.367 & 2.367 & 4.267 & 4.300 \\
Level 1* & 8.333 & 8.700 & 3.433 & 3.667 & 5.533 & 5.633 \\
Level 2 & 7.600 & 7.833 & 3.267 & 3.467 & 5.233 & 5.367 \\
Level 3 & 6.900 & 7.100 & 2.833 & 3.133 & 5.133 & 5.267 \\
Level 1 + 4 kg compost & 11.56 & 12.200 & 4.117 & 4.500 & 6.720 & 6.733 \\
Level 2 + 4 kg compost & 10.26 & 10.53 & 3.767 & 3.933 & 6.300 & 6.367 \\
Level 3 + 4 kg compost & 9.700 & 10.20 & 3.533 & 3.700 & 5.867 & 5.867 \\
LSD at 5\% & 0.409 & 0.389 & 0.182 & 0.183 & 0.280 & 0.297 \\
\hline
\end{tabular}

* Leavel 1 Magnetic water 3658.5, Leavel 2 Magnetic water 2743.8 and Leavel 3 Magnetic water 1829 m ${ }^{3} / \mathrm{fed}_{\text {/season. }}$

Leaf surface area, leaf dry weight and leaf specific weight:

Data presented in Table (5) showed leaf area/leaf $\left(\mathrm{cm}^{2}\right)$, leaf dry weight $(\mathrm{g})$ and specific leaf weight $\left(\mathrm{mg} / \mathrm{cm}^{2}\right)$ recorded significant increase when irrigated with all magnetic water plus $4 \mathrm{~kg}$ compost as compared with magnetic water alone and control (non-magnetic) in both seasons. In addition, level $1+4 \mathrm{~kg}$ compost had significant increase on same characteristics than another studied treatments in two seasons of the study. These results are in agreement with those of Ibrahim (2001) on Cleopatra mandarin, Balaganvi and Kumathe (2004) on 
Kagzi Lime trees and El-Abd (2005) on Washington Navel orange trees. They found that there were positive relation between irrigation amounts and leaf area. However, EL-Sayed (2014) showed that the stimulatory impact of magnetic water may be ascribed to the improving the growth parameters (plant height, leaves fresh and dry weight and leaf surface area) which increased absorption and assimilation of nutrients and also increased chemical constituents (chlorophyll a and b). Also, Saied (2004) and Hegazi et al. (2007).
Concluded that there were positive relation between compost application and leaf area. Such findings are in harmony with those reported by Hussien et al. (2013), Zalat (2014) on Washington Navel orange trees and ELSayed (2014), El-Abd (2005) on Washington Navel orange trees and Fiorella et al. (2015) on mature orange trees cv. "Tarocco Meli" who found that irrigated trees with magnetic water increased leaf dry weight and specific leaf weight,.

Table (5): Effect of magnetic irrigation water levels and compost on leaf area, leaf dry and leaf specific weight of Washington Navel orange trees in 2014 and 2015 seasons.

\begin{tabular}{lcccccc}
\hline & \multicolumn{2}{c}{ Leaf area/leaf $\left(\mathbf{c m}^{\mathbf{2}}\right)$} & \multicolumn{2}{c}{$\begin{array}{c}\text { LSW } \\
\left(\mathbf{m g} / \mathbf{c m}^{\mathbf{2}}\right)\end{array}$} & \multicolumn{2}{c}{$\begin{array}{c}\text { Leaf dry weight(g) } \\
\text { Treatments }\end{array}$} \\
& $\begin{array}{c}\mathbf{2 0 1 4} \\
\text { season }\end{array}$ & $\begin{array}{c}\mathbf{2 0 1 5} \\
\text { season }\end{array}$ & $\begin{array}{c}\mathbf{2 0 1 4} \\
\text { season }\end{array}$ & $\begin{array}{c}\mathbf{2 0 1 5} \\
\text { season }\end{array}$ & $\begin{array}{c}\mathbf{2 0 1 4} \\
\text { season }\end{array}$ & $\begin{array}{c}\mathbf{2 0 1 5} \\
\text { season }\end{array}$ \\
\hline Control(non- magnetic water) & 19.07 & 20.59 & 0.640 & 0.643 & 0.162 & 0.159 \\
Level 1 & 25.30 & 26.36 & 0.667 & 0.667 & 0.165 & 0.168 \\
Level 2 & 24.56 & 24.50 & 0.620 & 0.627 & 0.152 & 0.154 \\
Level 3 & 23.43 & 23.86 & 0.603 & 0.613 & 0.141 & 0.142 \\
Level 1 + 4 kg compost & 30.52 & 30.46 & 0.847 & 0.837 & 0.194 & 0.195 \\
Level 2 + 4 kg compost & 27.68 & 26.07 & 0.670 & 0.677 & 0.185 & 0.187 \\
Level 3 + 4 kg compost & 26.24 & 26.53 & 0.653 & 0.677 & 0.174 & 0.176 \\
LSD at 5\% & 3.56 & 2.40 & 0.08 & 0.07 & 0.008 & 0.008 \\
\hline
\end{tabular}

* Level 1 magnetic water 3658.5, level 2 magnetic water 2743.8 and level 3 magnetic water $1829 \mathrm{~m}^{3} / \mathrm{fed}$. Season .

\subsection{Yield efficiency and water use efficiency:}

As shown in Table (6) data cleared that yield efficiency (YE) which determined as $\mathrm{kg} / \mathrm{cm}^{3}$ of canopy volume, $\mathrm{kg} / \mathrm{cm}^{2}$ of trunk cross section area (TCSA) and water use efficiency $\left(\mathrm{kg} / \mathrm{cm}^{3}\right)$. As for yield efficiency as $\mathrm{kg} / \mathrm{cm}^{3}$ of canopy volume data indicated that there was an inverse relationship among studied magnetic of irrigation water either with compost or without it and yield efficiency in term of $\mathrm{Kg} / \mathrm{m}^{3}$ of tree canopy and $\mathrm{Kg} / \mathrm{m}^{3}$ of TCAS of tree during both season of the study. Also, data of water use efficiency $\left(\mathrm{Kg} / \mathrm{m}^{3}\right)$ was in line with the same previous results of yield efficiency components in terms of $\mathrm{Kg} / \mathrm{m} 3$ of tree canopy and $\mathrm{Kg} / \mathrm{m}^{3}$ of TCSA in 2014 and 2015 season in this work. In vein control treatment (non-magnetic) gave significant decrease on both tested attributes of yield efficiency in terms of $\left(\mathrm{Kg} / \mathrm{m}^{3}\right.$ of canopy and $\mathrm{Kg} / \mathrm{m}^{3}$ of TCSA) and water use efficiency $\left(\mathrm{Kg} / \mathrm{m}^{3}\right)$. These findings supported with those previously reported by
Pérez-Pérez et al. (2008) on mature "Lan late" sweet orange trees and Ennab and El-Sayed (2014) on Balady mandarin trees. With respect to water use efficiency (WUE) values, are used to evaluate the effectiveness of irrigation treatments for maximum utilization of water supplies. The highest significant values of WUE were obtained from irrigation treatment at level $3+4 \mathrm{~kg}$ compost $\left(4.907\right.$ and $\left.5.514 \mathrm{~kg} / \mathrm{m}^{3}\right)$ compared to the control which gave the lowest values (1.671 and 1.802) in both seasons, respectively. All differences found were statistically significant. As for water use efficiency values results were in agreement with those obtained by Abo El-Enin (2012) on Washington Navel trees, Panigrahi et al. (2014) on 'Kinnow' mandarin trees, Fiorella et al. (2015) on Orange trees cv. "Tarocco Meli" and Stagno et al. (2015) Orange trees cv. "Tarocco Meli". They mentioned that a gradual decrease in WUE values due to increase the amount of applied irrigation water.

Tabel (6): Effect of magnetic irrigation water levels and compost on yield efficiency and water use efficiency of Washington Navel orange trees in 2014 and 2015 seasons.

\begin{tabular}{lcccccc}
\hline & \multicolumn{3}{c}{ Yield efficiency (YE) } & \multicolumn{2}{c}{ Water ues effcieney } \\
Treatments & $\mathbf{K g} / \mathbf{m}^{\mathbf{3}}$ of canopy & $\mathbf{K g} / \mathbf{m}^{\mathbf{2}}$ of $\mathbf{~ T C S A ~}$ & \multicolumn{2}{c}{ WUE $\left(\mathbf{k g} / \mathbf{m}^{\mathbf{3}}\right)$} \\
& $\mathbf{2 0 1 4}$ & $\mathbf{2 0 1 5}$ & $\mathbf{2 0 1 4}$ & $\mathbf{2 0 1 5}$ & $\mathbf{2 0 1 4}$ & $\mathbf{2 0 1 5}$ \\
& season & season & season & season & season & season \\
\hline Control(non-magnetic) & 4.114 & 4.034 & 0.432 & 0.385 & 1.671 & 1.802 \\
Level 1 & 4.657 & 4.829 & 0.487 & 0.433 & 2.247 & 2.680 \\
Level 2 & 5.085 & 5.315 & 0.519 & 0.436 & 2.877 & 3.492 \\
Level 3 & 5.360 & 5.634 & 0.549 & 0.492 & 4.107 & 5.053 \\
Level 1 + 4 kg compost & 4.821 & 4.730 & 0.552 & 0.457 & 3.204 & 3.546 \\
Level 2 + 4 kg compost & 5.438 & 5.301 & 0.674 & 0.468 & 4.064 & 4.514 \\
Level 3 + 4 kg compost & 5.555 & 5.410 & 0.735 & 0.559 & 4.907 & 5.514 \\
LSD at 5\% & 0.81 & 0.80 & 0.09 & 0.07 & 0.05 & 0.04 \\
\hline
\end{tabular}

* Level 1 magnetic water 3658.5, level 2 magnetic water 2743.8 and level 3 magnetic water 1829 m $3 /$ fed/season. 


\section{Leaf mineral content:}

In this concern, leaf $\mathrm{N}, \mathrm{P}, \mathrm{K}, \mathrm{Ca}, \mathrm{Mg}$ and $\mathrm{Na}$ contents of Washington Navel orange were investigated pertaining the response to effect of irrigation levels and compost treatments Tables (7 and 8).

Nitrogen, phosphorus and potassium (N, P and K):

Table (7) displayed that leaf $\mathrm{N}, \mathrm{P}$ and $\mathrm{K}$ responded by treatments. Hence, irrigated Washington Navel trees with level $2+$ compost had statistically the higher constant leaves in N, P and $\mathrm{K}$ of leaves followed by irrigation treatment at level $1+$ compost , while the reverse was true with control in both seasons. A similar observation has been reported by El-Sabrout and Kassam (2002), Wassel et al. (2007a) on Balady mandarin trees, Abo El-Enin (2012) worked on Washington navel orange trees and Panigrahi (2014) on mandarin trees, they showed that the percentage of nitrogen, phosphorus and potassium in the leaves were increased by moderate irrigation levels. In addition, Abd EL-Latif et al. (2014) on Pear seeding and Aly et al. (2015) cleared that application of magnetic water increased (N, P and $\mathrm{K}$ ) in Valencia orange leaves when compared to trees which irrigated with non-magnetic water (control). Also, Mansour and Shaaban (2007) found that, fertilized Washington Navel orange trees with compost El-Neel at $11.63 \mathrm{~kg} /$ tree increased $\mathrm{N}, \mathrm{P}$ and $\mathrm{K}$ contents in the leaves compared to untreated trees.

Calcium, magnesium and sodium:

As for $\mathrm{Ca}, \mathrm{Mg}$ and $\mathrm{Na}$ contents, data in Table (8) revealed that, irrigation treatment at level 3 gave the highest Ca content (2.47 and 2.49\%) and $\mathrm{Mg}$ (0.386 and
$0.386 \%)$ compared to the lowest values of $\mathrm{Ca}$ (1.55 and $1.56 \%)$ and $\mathrm{Mg}(0.29$ and $0.29 \%)$ obtained by irrigation treatment at level $1+$ compost in both seasons. The differences between all treatments were statistically significant. Looking for $\mathrm{Na}$ content, data showed that control, irrigation treatment at level 1 and level 2 gave the highest $\mathrm{Na}$ content in leaves without significant differences between them in the first season, but in the second one control treatment increased $\mathrm{Na}$ content followed irrigation at levell compared to the lowest values $(0.166$ and $0.166 \%)$ recorded by irrigation at level $1+$ compost in both seasons, respectively. These results are in line with those obtained by Ismail (2007) on sweet orange trees and Abo El-Enin (2012) worked on Washington navel orange trees and found that trees irrigated at $70 \%$ of field capacity (FC) had higher $\mathrm{Ca}$ and $\mathrm{Mg}$ in then levels. However, EL-Sayed (2014) indicated that the irrigation of broad bean plant with magnetic water exhibited an increase in Ca contents and decreased $\mathrm{Na}$ in then leaves compared with control. Generally, increasing leaf N,P,K,Ca and $\mathrm{Mg}$ contents and decreasing $\mathrm{Na}$ content may indicate the role of magnetic water in reducing the harmful effects of salinity through solubilizing $\mathrm{NaCl}$ salt and leaching it out of the soil. Therefore, the plants do not uptake higher amounts of either $\mathrm{Na}$ or $\mathrm{Cl}$. Also, the magnetic water improved dissolving of fertilizers in the soil irrigated with magnetized water and increase in the rate of water absorption, and explained the results by the variations induced by magnetic fields in the ionic currents across the cellular membrane with leads to change in the osmotic pressure. (Carbonell et al 2004).

Table (7): Effect of magnetic irrigation water levels and compost on leaf $N, P$ and $K$ contents of Washington Navel orange trees in 2014 and 2015 seasons.

\section{Treatments}

Control (nonmagnetic water)

Level $1 *$

Level 2

Level 3

Level $1+4 \mathrm{~kg}$ compost

Level $2+4 \mathrm{~kg}$ compost

Level $3+4 \mathrm{~kg}$ compost

LSD at $5 \%$
2014 season 2015 season 2014 season 2015 season 2014 season 2015 season

$\begin{array}{llllll}2.617 & 2.630 & 0.190 & 0.190 & 1.240 & 1.240 \\ 2.750 & 2.807 & 0.217 & 0.210 & 1.363 & 1.247 \\ 2.310 & 2.370 & 0.167 & 0.167 & 1.070 & 1.060 \\ 2.217 & 2.193 & 0.150 & 0.147 & 0.903 & 0.923 \\ 3.240 & 3.287 & 0.257 & 0.243 & 1.573 & 1.570 \\ 3.443 & 3.427 & 0.270 & 0.257 & 1.773 & 1.773 \\ 3.020 & 2.990 & 0.243 & 0.230 & 1.467 & 1.467 \\ 0.161 & 0.074 & 0.024 & 0.007 & 0.093 & 0.141\end{array}$

Table (8): Effect of magnetic irrigation water levels and compost on leaf $\mathrm{Ca}, \mathrm{Mg}$ and $\mathrm{Na}$ contents of Washington Navel orange trees in 2014 and 2015 seasons.

\begin{tabular}{|c|c|c|c|c|c|c|}
\hline \multirow[b]{2}{*}{ Treatments } & \multicolumn{2}{|c|}{$\mathrm{Ca}(\%)$} & \multicolumn{2}{|c|}{$\operatorname{Mg}(\%)$} & \multicolumn{2}{|c|}{$\mathrm{Na}(\%)$} \\
\hline & $\begin{array}{c}2014 \\
\text { season } \\
\end{array}$ & $\begin{array}{c}2015 \\
\text { season } \\
\end{array}$ & $\begin{array}{c}2014 \\
\text { season } \\
\end{array}$ & $\begin{array}{c}2015 \\
\text { season } \\
\end{array}$ & $\begin{array}{c}2014 \\
\text { season } \\
\end{array}$ & $\begin{array}{c}2015 \\
\text { season }\end{array}$ \\
\hline Control(non-magnetic) & 2.200 & 2.200 & 0.356 & 0.358 & 0.239 & 0.239 \\
\hline Level $1 *$ & 2.070 & 2.070 & 0.347 & 0.344 & 0.230 & 0.229 \\
\hline Level 2 & 2.327 & 2.337 & 0.363 & 0.360 & 0.204 & 0.218 \\
\hline Level 3 & 2.470 & 2.490 & 0.386 & 0.386 & 0.182 & 0.204 \\
\hline Level $1+4 \mathrm{~kg}$ compost & 1.550 & 1.563 & 0.298 & 0.299 & 0.166 & 0.166 \\
\hline Level $2+4 \mathrm{~kg}$ compost & 1.693 & 1.707 & 0.314 & 0.310 & 0.178 & 0.179 \\
\hline Level $3+4 \mathrm{~kg}$ compost & 1.840 & 1.867 & 0.328 & 0.327 & 0.191 & 0.182 \\
\hline LSD at $5 \%$ & 0.093 & 0.076 & 0.012 & 0.013 & 0.038 & 0.009 \\
\hline
\end{tabular}




\section{REFERENCES}

Abd EL-Latif, O.E.A.; S. M. Hussien and A. E. A. herif (2014). Assessing the effect of irrigation with different levels of saline magnetic water on growth parameters and mineral contents of pear seedlings. Glob. J. Sci. Res., 2 (5): 128-136.

Abo El-Enin, M.M.S. (2012). Improvement of Washington Navel orange fruit quality using water regimes and $\mathrm{GA}_{3}$, potassium and calcium foliar applications. Ph.D. Thesis, Fac. Agric., Kafrelsheikh Univ., Egypt.

Aladjadjiyan A. (2010). Influence of stationary magnetic field on lentil seeds. Int. Agrophys., 24: 321-324.

Alikamanoglu S and Sen A. (2011). Stimulation of growth and some biochemical parameters by magnetic field in wheat (Triticum stivum L.) tissue cultures. African Journal of Biotechnology, 10: 10957-10963.

Aly, M.A., M. EZZ., S. S. M. Osama and A. A. Mazek (2015). Effect of magnetic irrigation water and some anti-salinity substances on the growth and production of Valencia orange. Middle East J. Agric. Res., 4(1): 88-98.

Balaganvi, S. and S. S. Kumathe (2004). Effect of different levels of drip irrigation and fertiliser application on growth, yield and quality parameters of Kagzi lime. Karnataka J. Agri. Sci., 17 (3): 626-628.

Barakat, M.R., T.A. Yehia and B.M. Sayed (2012). Response of Newhall navel orange to bio-organic fertilization under newly reclaimed area conditions I: Vegetative growth and nutritional status. J. Hort. Sci. \& Ornamen. Plants, 4 (1): 1825.

Brown, J.D. and O. Lillel land (1974). Rapid determination of potassium and sodium in plant material and soil extracts by flame photometer. Proc. Soc. Hort. Sci., 48: 341-346.

Carbonell MV, Florez M, Martinez E, Maqueda R and Amaya JM. (2011). Study of stationary magnetic fields on initial growth of pea (Pisum sativum L.) seeds. Seed Science and Technology, 39: 673679.

Chapman, H.D. and P.F. Pratt (1961). Methods of Analysis for Soils, Plant and Waters. Univ. of California, USA, pp. 169-170.

Chou, G.J. (1966). A new method of measuring the leaf area of citrus trees. Acta. Hort. Sin., 5: 17-20.

Duncan, B.D. (1955). Multiple range and multiple Ftest. Biometrics, J. 11: 1-42.

El-Abd, A.A. (2005) Influence of fertilization and irrigation on Washington Navel orange orchards. Ph.D. Thesis, Fac. Agric., Tanta Univ., Egypt.

El-Sabrout, M.B and H.A. Kassam (2002). 1. Effect of fertilization with nitrogen and potassium on vegetative growth, yield and leaf mineral content of Washington Navel orange trees grown in sandy soil. J. Adv. Agric. Res., 7(3): 539-553.
EL-Sayed, H.E.A (2014). Impact of magnetic water irrigation of improve growth the growth, chemical composition and yield production of bread ben (Vicia faba L) plants. American J. Experiment. Agriculture, 4(4): 476-496.

El-Sayed, M.E.A. (2014). Reducing mineral fertilization by using organic fertilization for "Superior seedless "Grapevines grafted on Freedom rootstock under calcareous soil. Middle East J. Agric. Res., 3(3): 417-424.

El-Sayed, S.A. and H.A. Ennab (2013). Effect of different levels of irrigation water and nitrogen fertilizer on vegetative growth, yield and fruit quality of Valencia orange trees. Minufiya J. Agric. Res., Vol. 38 No. 3(2): 761-773.

Ferre, D.C. and C.G. Forshey (1988). Influence of pruning and urea spray on growth and fruiting of square bound Delicious apple trees. J. Amer. Soc. Hort. Sci., 113(5): 699-703.

Hansen, J.E., A.A. Lacis., P. Lee., W.C Wang (1980) Climatic effects of atmospheric aerosols. Ann N Y Acad Sci 338:575-587.

Hegazi, E.S.; M.R. El-Sonbaty; M.A. Eissa; D.M. Ahmed and T.F. El-Sharony (2007). Effect of organic and bio-fertilization on vegetative growth and flowering of Picual olive trees. World $\mathrm{J}$. Agric. Sci., 3 (2): 210-217.

Hilal, M. H. and Hillal, M. M. (2000). Application of magnetic technologies in desert agriculture. IIEffect of magnetic treatments of irrigation water on water on salt distribution in olive and citrus field and induced changes of ionic balance in soil and plant. Egypt. J. Soil Sci. 40 :(3),423-435.

Hussien, S.M.; E.A. Ismail; M.N.H. Ismail and T.A. Eid (2013). Effect of applying surface and bubbler irrigation systems on fruitful Washington Navel orange trees production. Egypt J. Agric. Res., 91 (4): $1565-1580$.

Ibrahim, M.A. (2001). The effect of different water regimes on morphological, physiological and anatomical characteristics of some citrus rootstocks. Ph.D. Thesis, Fac. Agric., Cairo Univ., Egypt.

Ismail, M.N.H. (2007). Physiological studies on creasing of sweet orange. Ph.D. Thesis, Fac. Agric. Benha Univ.

Jackson, M.L. (1967). Soil Chemical and Analysis. Prentice Hall of India, New Delhi, p. 498.

Júnior, J.A.; M.V. Folegatti; C.R.D. Silva; T.J.A.D. Silva and A.W.P. Evangelista (2011). Response of young 'Tahiti' acid lime trees to different irrigation levels. Eng. Agríc. Jaboticabal, 31(2): 303-314.

Mansour, A.E.M. and E.A. Shaaban (2007). Effect of different sources of mineral $\mathrm{N}$ applied with organic and bio fertilizers on fruiting of Washington Navel orange trees. J. Appl. Sci. Res., 3(8): 764-769.

Mohamed, A. I (2013). Effects of magnetized of low quality water on some soil properties and plant growth. Int. J. Res. Chem. Environ. 3(2): 140147. 
Munns, R. (1993). "Physiological Processes Limiting Plant Growth in Saline Soil: Some Dogmas and Hypotheses," Plant, Cell \& Environment, 16:1524. doi:10.1111/j.1365-3040.1993.tb00840.x

Murphy, J. and Riley, J.R. (1962). A modified single solution method for the determination of phosphour in natural water. Anal. Chem., Acta, 27: 31-38.

Natcheh, B and S. Mousa (2014). Effect of Organic and Inorganic Fertilizers Application on Plant Productivity. International Journal of Agriculture and Forestry, 4(3): 166-170.

Panigrahi, P. (2014). Response of drip-irrigated Kinnow mandarin to deficit irrigation under a semiarid climate. 2nd International Conference on Agriculture \& Horticultural Sciences, 3-5 February, Hyderabad, India.

Pregl, F. (1945). Quantitative organic microanalysis, 4th ed J.A. Churchill, Ltd, London.

Radhakrishnan, R and B. D. R. Kumari (2012). Pulsed magnetic field: A contemporary approach offers to enhance plant growth and yield of soybean. Plant Physiology and Biochemistry, 51: 139-144.

Saied, K.M. (2004). Response of Washington navel orange trees growing on sandy soil in mixture of some organic fertilizers. Assiut J. of Agric. Sci., 35(2):215-235.

Shiralipour, A.; D. McConnell and W. Smith (1992). Phyiscal and chemical properties of soils as affected by municipal solid waste compost application. Biomass and Bioenergy, 3: 261-266.
Snedecor, G.W. and W.G. Cochran (1977). Statistical methods. 6th Ed. Iowa State Univ. Press. Ames., Iowa, USA.

Stagno, F.; F. Intrigliolo; S. Consoli; A. Continella; and G. Roccuzzo (2015). Response of orange trees to deficit irrigation strategies: effects on plant nutrition, yield, and fruit quality.J.Irrig.Drain.Eng.141(10):40-50.

Wardowski, W.F.; S.W. Grierson (1985). Fresh citrus fruits. Avi. Pub. Co., Inc., Westport, USA, pp. 79-83.

Wassel, A.H.; F.F. Ahmed; MA. Ragab and M.M. Ragab (2007). Response of Balady mandarin trees to drip irrigation and nitrogen fertigation. I. Effect of nitrogen fertigation and drip irrigation on the vegetative growth and the yield of Balady mandarin trees (Citrus reticulate Blanco). African Crop Sci. Conference Proceeding, 8: 503-511.

Wilde, S.A.; R.B. Corey; J.G. Layer and G.K. Voigt (1985). Soil and plant analysis for tree culture. Published by Mohan Primlani, Oxford, IBH, Publishing Co., New Delhi, pp. 1-142.

Zalat, M. E. E (2014). Impact of organic and biofertilization as a partial substitute for mineral nitrogen on vegetative growth, yield and fruit quality of "Washington Navel" orange trees.

Zhou, X. W; L. Z. Yi; L. Bin; C. Z. Nian; X. Lijun and Y. Y. Wen (2001). Study on the improvement of the soil of the newly established orchard on the reclaimed purple soil. Journal of Fruit Sci., 18(1): 15-19.

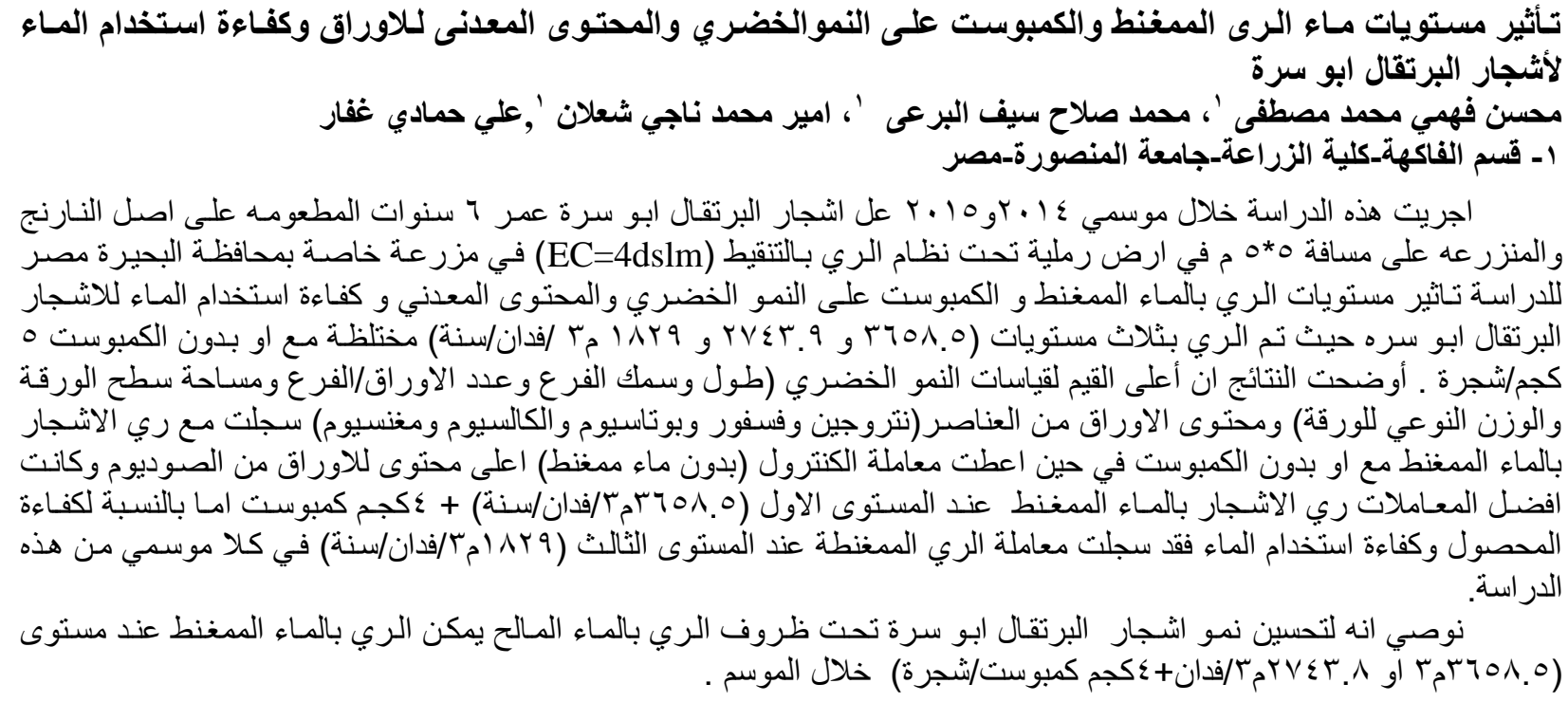

